\title{
Perception on the Online Classes Challenges Experienced during the COVID-19 Pandemic by LSPU Computer Studies Students
}

\author{
Marco Jr. N. Del Rosario* ${ }^{*}$ and Ronnel A. dela Cruz \\ Laguna State Polytechnic University, San Pablo City, Laguna, Philippines
}

\begin{abstract}
The COVID-19 pandemic forces educational institutions to divert from traditional face-to-face classes to online classes. Despite the implementation and acceptance of the general population on this setup, various challenges are being experienced by the students. Through a literature review, this study determined the challenges of online classes faced by the students which commonly fall in the following domains: technology, digital competency, compatibility, socioeconomic factor, human and pets' intrusions or noise, demanding workload, assessment and supervision, time management and motivation, and social and emotional health. The study further investigated the constructs of the challenges based on the students' responses. To gain breadth and depth of understanding on the challenges, both quantitative and qualitative research and data were mixed and used. The result in the quantitative method shows that the level of agreement of the students, if they are experiencing problems in terms of communication and interaction, teaching methodologies of the instructors, and learning resources, revealed to be neutral. However, analysing the qualitative results shows that there are recurring themes in the challenges such as poor or unstable internet connection, human intrusion and noise, feedback and communication issues, and issues in delivering teaching and learning. Further, this research has implications for advising faculty, curriculum designers and administrators on the needs and experiences of the students which can provide insights in planning and designing of teaching and learning delivery for the coming semesters.
\end{abstract}

Keywords: online learning; distance learning; learning challenges; COVID-19 pandemic

\section{Introduction}

The world faces a health crisis due to the transmissible coronavirus disease (COVID-19). This global occurrence caused the suspension of the country's operations, with the education sector being one of those that are affected. Upon

\footnotetext{
*Corresponding author: Marco Jr. N. Del Rosario, macky.delrosario@lspu.edu.ph
} 
the advice of the Commission on Higher Education (CHED) in terms of the suspension of face-to-face classes, the implementation of the traditional enrolment process and teaching (face-to-face) is not permitted (De Vera III 2020). Educational institutions, however, did not remain impotent with the situation as they pushed for a solution in the form of online technologies which are now utilized in implementing enrolment processes and teaching activities.

The use of technology can transform teaching into a new model of connecting to students. It will equip classrooms with digital learning tools, improve motivation, increase students' engagement, and assist the instructors in developing instructional methodologies that will help students develop socalled 21st-century skills. In achieving those, the institution needs to check the resources available and the capacity of both students and instructors to switch from traditional face-to-face classes to online classes.

The Laguna State Polytechnic University envisions to provide quality, efficient and effective delivery of instruction amidst the pandemic. A set of guidelines and policies were formulated to ensure that the goal of the university will still be achieved. In the formulation of the said guidelines and policies, the University conducted a study that will determine the capacity of the students to adapt to the "new normal". Familiarity and capability of students, device availability and internet access, and technology experience all have a major impact on their readiness to participate in online teaching and learning, according to the study findings of Callo and Yazon (2020). Determining and understanding the readiness is important in the preparation of conducting online classes, however, determining and understanding the challenges being encountered during the implementation of online learning is another thing. Even though online learning has been fully accepted and seen effective, there are still inevitable challenges that need to be looked upon (Barrot et al., 2021). Chiu et al. (2021) suggest that, for the time being, it is important and critical for researchers to reflect on and enhance present online learning and teaching techniques using proper designs and evidence-based strategies.

This study focuses on the student's perception of the challenges they experienced in online classes during the COVID-19 pandemic. With the intent to continually improve the delivery of the service of the institution to its clientele, the researchers aim to identify the experiences and challenges encountered by the students in online learning. The result of the study will be of great help to further improve the strategies of the instructors in the delivery of their instruction and will further improve the University's plans in the delivery of quality, efficient and effective teaching, and learning.

\section{Literature Review}

Online learning refers to the use of technological resources available through a computer or a device wherein learning can be achieved by going through a goal of extracting substance or can be a by-product of an experience (Saul, 2004). Anshari et al. (2016) specified that online learning has become the standard 
practice by many education institutions which use information and communication technologies (ICT) in managing the processes of learning and delivering teaching. According to Gillett-Swan (2017), higher education institutions are providing a range of options for engagement to the current and potential learners. This could be done in a variety of ways, including traditional face-to-face delivery (internal), online learning (external), or mixed (blended) modality. Hermanto and Srimulyani (2021) agreed that these variety of ways or learning model along with the current technological development enables the well implementation of online learning. In higher education settings, a popular method for delivering teaching and learning is through online education (Koh \& Hill, 2009). Some studies suggest that the online learning environment can help students develop critical thinking and reflection skills.

Online education is not entirely a new concept as it is already existent and booming from the early 1980s and 1990s to the 2000s (Anshari et al., 2016; Ribeiro, 2020). Ribeiro added that online learning, at that point, was only considered as an alternative way of delivering education other than face-to-face or the traditional classroom setup. It was not considered as a plan for continuity for education. In the early 2000s, people dismissed the possibility that online learning might replace traditional face-to-face classes (Saul, 2004). As time goes by, this point of view changes. Online education as an option for delivering instructions became the continuity plan for the delivery of instruction to most educational institutions when the traditional face-to-face approach is no longer possible due to the limitations brought about by the pandemic (Ribeiro, 2020).

Since the pandemic forced educational institutions to deliver their instructions online, the need to know the challenges of this modality is important. Kumar (2015) states that although students are attracted to online education because of its time and place flexibility, many of them are being prevented from finishing their courses because serious challenges are encountered along the way. In addition, Pappas (2014) stated that online education has roadblocks that hinder the students from absorbing instructions and teachings. Several challenges associated with implementing online learning were highlighted in this literature review. Table 1 outlines the most prevalent issues that students face when taking online classes based on findings from multiple studies. Based on the previous studies, the following nine domains were identified:

Table 1: Aspects of Previous studies on challenges faced in Online Learning.

\begin{tabular}{|c|c|c|}
\hline Challenges & Description & Literature \\
\hline Technology & $\begin{array}{l}\text { This refers to the dependency of online } \\
\text { learning on technology in terms of } \\
\text { accessibility and availability of devices } \\
\text { and internet connection. }\end{array}$ & $\begin{array}{l}\text { Adedoyin \& Soykan (2020), } \\
\text { Alam (2020), Gilbert (2015), } \\
\text { Kumar (2015), Friedman } \\
\text { (2020), Almaiah et al. (2020), } \\
\text { Cheng (2020), Koh \& Hill } \\
\text { (2009), Barrot et al. (2021), } \\
\text { Hermanto \& Srimulyani } \\
(2021) \text {, Yusuf \& Ahmad } \\
(2020)\end{array}$ \\
\hline
\end{tabular}




\begin{tabular}{|c|c|c|}
\hline Challenges & Description & Literature \\
\hline $\begin{array}{l}\text { Socioeconomic } \\
\text { Factor }\end{array}$ & $\begin{array}{l}\text { This refers to the tendency of students to } \\
\text { fall behind in learning and to meet more } \\
\text { challenges due to low or no socio- } \\
\text { economic power to have a stable } \\
\text { internet connection. }\end{array}$ & $\begin{array}{l}\text { Adedoyin \& Soykan (2020), } \\
\text { Alam (2020), Gilbert (2015), } \\
\text { Kumar (2015), Almaiah et al. } \\
\text { (2020), Barrot et al. (2021) }\end{array}$ \\
\hline $\begin{array}{l}\text { Human and pets' } \\
\text { intrusions }\end{array}$ & $\begin{array}{l}\text { This refers to the possibility of student } \\
\text { distraction caused by noise, disruption, } \\
\text { or interruption from pets and family } \\
\text { members which affects the focus and } \\
\text { attention during online classes. }\end{array}$ & $\begin{array}{l}\text { Adedoyin \& Soykan (2020), } \\
\text { Friedman (2020), Barrot et } \\
\text { al. (2021) }\end{array}$ \\
\hline Digital competence & $\begin{array}{l}\text { This refers to the knowledge and set of } \\
\text { skills required to utilize technological } \\
\text { devices to perform tasks and activities } \\
\text { conducted during online classes. }\end{array}$ & $\begin{array}{l}\text { Adedoyin \& Soykan (2020), } \\
\text { Alam (2020), Kumar (2015), } \\
\text { Friedman (2020), Cheng } \\
\text { (2020), Kearns (2012) }\end{array}$ \\
\hline $\begin{array}{l}\text { Assessment and } \\
\text { supervision }\end{array}$ & $\begin{array}{l}\text { This refers to the instructors' } \\
\text { responsibility to assess the performance } \\
\text { tasks given to the students, assure that } \\
\text { they achieve the learning objectives, and } \\
\text { be able to provide feedback and } \\
\text { intervention. }\end{array}$ & $\begin{array}{l}\text { Adedoyin \& Soykan (2020), } \\
\text { Alam (2020), Gilbert (2015), } \\
\text { Friedman (2020), Almaiah et } \\
\text { al. (2020), Cheng (2020), } \\
\text { Kearns (2012) }\end{array}$ \\
\hline Heavy workload & $\begin{array}{l}\text { This refers to the effort of an educational } \\
\text { institution to provide the necessary ICT } \\
\text { equipment, facilities, and platform to } \\
\text { accommodate the online classes. }\end{array}$ & $\begin{array}{l}\text { Adedoyin \& Soykan (2020), } \\
\text { Almaiah et al. (2020), Kearns } \\
\text { (2012), Hermanto \& } \\
\text { Srimulyani (2021), Yusuf \& } \\
\text { Ahmad (2020) }\end{array}$ \\
\hline Compatibility & $\begin{array}{l}\text { This refers to the idea where online } \\
\text { learning is perceived to be inapplicable } \\
\text { to other disciplines in terms of } \\
\text { effectivity and efficiency. }\end{array}$ & $\begin{array}{l}\text { Adedoyin \& Soykan (2020), } \\
\text { Hermanto \& Srimulyani } \\
(2021)\end{array}$ \\
\hline $\begin{array}{l}\text { Time Management } \\
\text { and Motivation }\end{array}$ & $\begin{array}{l}\text { This refers to the students' tendency to } \\
\text { poorly manage their time and } \\
\text { experience lack of motivation to finish } \\
\text { their tasks and activities on time and in } \\
\text { good quality. }\end{array}$ & $\begin{array}{l}\text { Alam (2020), Gilbert (2015), } \\
\text { Kumar (2015), Friedman } \\
\text { (2020), Cheng (2020), Kearns } \\
\text { (2012), Barrot et al. (2021), } \\
\text { Hermanto \& Srimulyani } \\
\text { (2021), Chiu et al. (2021), } \\
\text { Yusuf \& Ahmad (2020) }\end{array}$ \\
\hline $\begin{array}{l}\text { Social and } \\
\text { Emotional Health }\end{array}$ & $\begin{array}{l}\text { This refers to the belief that lacking peer } \\
\text { interaction and experiencing unstable } \\
\text { emotions can negatively influence the } \\
\text { learning process of a student and the } \\
\text { efficacy of teaching. }\end{array}$ & $\begin{array}{l}\text { Gilbert (2015), Friedman } \\
\text { (2020), Almaiah et al. (2020), } \\
\text { Cheng (2020), Koh \& Hill } \\
\text { (2009), Barrot et al. (2021), } \\
\text { Hermanto \& Srimulyani } \\
\text { (2021), Chiu et al. (2021) }\end{array}$ \\
\hline
\end{tabular}

Kumar (2015) stated that there are five common problems that are encountered by the students. Adaptability challenges, technological issues, computer literacy, time management, and self-motivation are all on the list. Friedman (2020), on the other hand, listed seven challenges that a student is now encountering. Technical difficulties, handling distractions, time management, staying motivated, 
comprehending course expectations, a lack of in-person engagement, adjusting to unfamiliar technologies, and concern about the future are all examples. Gilbert (2015) discovered that there are several disadvantages and potential concerns that students may encounter while participating in an online class. $\mathrm{He}$ revealed that participating in an online class may raise issues about academic rigor, medium of delivery, community and peer interaction, cultural restrictions, availability and accessibility of technological devices to students, maintaining motivation, and students' comprehension.

In a study conducted by Adedoyin and Soykan (2020), they found out that during the COVID-19 pandemic, there are various impediments to the digital transformation of instructional operations. Technology, socioeconomic factors, human and animal intrusions, digital competency, assessment and supervision, heavy workload, and compatibility are the factors to consider. In a similar study conducted in Bangladesh by Alam (2020), he identified that some faculty and students are encountering difficulties like adaptability struggle, poor accessibility of the internet for online connectivity, low literacy in using computers and mobile devices, time management, managing feedback, and engaging students.

During the COVID-19 pandemic, Almaiah et al. (2020) did a study to investigate the main problems and factors affecting the use of the E-learning system. The exploration uncovered concerns such as change management, E-learning system technical issues, financial support, technological factors, E-learning system quality factors, cultural factors, self-efficacy factors, and trust components. In a study of Yusuf and Ahmad (2020), they listed the following challenges: students are less focused in online learning, availability and suitability of resources, internet connectivity, and issues in time and schedule in terms of length of class and attendance of students to classes. The aforementioned findings suggest that institutions should provide convenient platforms and improved facilities.

In a two-phased study conducted by Kearns (2012), the second phase focuses on identifying what are the best practices and challenges the faculty encountered in creating and deploying assessment and its impact in their face-to-face assessment through focus group discussion. The result highlighted three main themes which are the impact of physical distance, adapting to the technology used for communication, and time and workload management. Moreover, two other challenges emerged which are challenges in assessment and feedback.

Hermanto and Srimulyani (2021) found in their study that building communication between students and educators is challenging. There is also a need to improve current IT infrastructure to support online learning. Aside from constraint in internet and device availability, they also found that students and educators experience challenges related to lacking motivation, concentration, and discipline. The results added that it is still important to have a physical connection between educators and students. In relation to motivation, Chiu et. al (2021) conducted a study regarding the effect of motivation in online classes 
during the pandemic and mentioned that the pandemic's fear and anxiety can easily demotivate and alienate students from learning.

In a study by Cheng (2020), he described the challenges of "School's Out, But Class's On" in several aspects, specifically, in terms of traditional forms of school education, teachers' teaching methods, student's learning styles, and school administration. Koh and Hill (2009) state that students and faculty participating in online learning may have a negative effect on the overall class experience due to lacking or reduced sense of connection. Additionally, they found out that difficulty in communication due to technical problems is also a challenge in online learning.

\section{Methodology}

A concurrent nested mixed method design was implemented in this study. Only one data collection phase was done, which quantitative method nests the qualitative method. This was done to gain a broader and in-depth perspective.

\subsection{Research Question}

This study tends to investigate the constructs of the challenges faced by the students during the online classes. The outcome of the study will serve as baseline information to be used by the college to develop or improve policies relevant and responsive to the following semesters. Hence, this study intends to answer the following research questions:

1. What are the students' perceptions about the communication and interaction in the class, the teaching methodologies used by the instructors, and their learning resources and economic burden?

2. What are the difficulties the students encountered during the online classes?

To address the study's questions, a mixed methods research design has been conducted by employing a developed questionnaire.

\subsection{Participants}

In terms of data gathering, a purposive sampling technique was implemented, specifically aimed at the stakeholders relevant to the study. The exact sampling size was not rigorous and was subjected to the limitations presented by the research locale. The participants of the study are the students from the College of Computer Studies in Laguna State Polytechnic University enrolled in the first semester of the academic year 2020-2021.

\subsection{Instrument}

The study employed a questionnaire that solicited students' perceptions about the challenges they have faced in the duration of the online classes. There are three sections to the questionnaire. The first section dealt with the students' demographic profiles. The students' perceptions towards some of the challenges were the focus of the second section. It contains nine (9) statements concerning the challenges. The students used a five-point agreement Likert Scale ranging from (1) strongly disagree to (5) strongly agree to rate the statements. The 
following entries are included in the second section of this online survey instrument:

1. Communication and Interaction - It is a three-item questionnaire that solicits the respondents' agreement with regard to communicating with their instructors and classmates.

2. Teaching Methodologies - It is a three-item questionnaire that solicits the respondents' satisfaction in the delivery of instructions, availability of technical support from the instructor, and interaction during classes.

3. Learning Resources and Economic Burden - It is a three-item questionnaire that solicits the respondents' satisfaction in the instructional materials provided, capacity to provide gadgets/devices, and internet connectivity during online classes.

The third section consisted of two open-ended questions, namely 1) How was your experience communicating with your classmates and instructors? And 2) What are the specific difficulties you encountered, if any, during online classes?

The researcher-made survey questionnaire was created by first determining the survey's goals and time limits; second, planning on the process on how the questionnaire will be administered; and third, deciding on the format for the questions and begin composing them. The validation of the questions follow by enlisting the expertise of a subject matter expert, who evaluated the questions to see if they properly encapsulated the topic under consideration. Finally, Cronbach's alpha was utilized to determine the internal consistency of the researcher-made survey questionnaire. Each set of questions were subjected to Cronbach's alpha and were calculated. The reliability index for Communication and Interaction, Teaching Methodologies, and Learning Resources and Economic Burden set of questions are $a=0.76, a=0.81$, and $a=0.71$, respectively.

The questionnaire was encoded by the authors in Google form, wherein the link of the online survey questionnaire was sent through email and relevant social media channels, to the students of Laguna State Polytechnic University-San Pablo City Campus enrolled in BS Information Technology and BS Computer Science. Data collection lasted for two (2) weeks from March 1 to 12, 2021. Respondents were informed of the purpose of the study through the questionnaire and were assured of the privacy and security of the data that they have provided.

\subsection{Data Analysis}

The data was extracted from the Google form. Descriptive statistics including mean, standard deviation, and frequency count in percentage were used to compute and assess it. The qualitative data from the third section of the questionnaire which are open-ended questions were summarized and clustered to identify patterns or recurring themes through a narrative thematic analysis. On doing so, the data gathered from the responses of the participants to the open-ended questions were organized and any rudimentary patterns were noted 
in the response sheets. The participants were assigned fictitious names, and any participant identifiers were removed.

The analysis of qualitative data undergone the following steps (Braun \& Clarke, 2006; Swart, 2019): (1) Familiarization with the collected data by reading and rereading the responses; (2) Generate initial labels based on the nine online class challenges determined earlier shown in Table 1. The data coding and the actual data analysis was carried out manually. Labels were used to create themes to present the data in coherent and meaningful way (Sutton \& Austin, 2015); (3) Search for themes or main ideas that may provide general concepts. Re-reading of the transcripts was necessary to identify recurring words or prominent ideas generated from the data; (4) Review the found general concepts to ensure that they clearly and accurately encompass the ideas on the responses; (5) The themes were defined and labelled appropriately to the data; and (6) then a report as a result was produced. Finally, the categories were made, and these categories of responses reflected the themes that represent the major findings of the study. For this study, the codes were condensed into two categories including: communication and challenges during the online classes of the students.

\section{Results and Discussion}

In this section of the paper, quantitative and qualitative data results from the survey questionnaire are organized into two sections to address the study questions.

\subsection{Demographics}

The college's total population was 706 students. However, only 421 responses were collected. This sample size is $59.63 \%$ of the student population of the college. Among these respondents are from the 318 responses of students pursuing their bachelor's degree in Information Technology. They cover 75.53\% of the total responses. Meanwhile, there are 103 students pursuing a bachelor's degree in Computer Science, which is $24.47 \%$ of the total responses. Regarding the respondents' sex, most of the respondents are males. They account for $56.77 \%$ of the total respondents, while the female counterpart accounts for $43.23 \%$. It can be inferred that there is a nearly balanced distribution from both sexes.

\subsection{Students' perceptions towards some of the challenges}

Question 1: Student Perceptions towards the Challenges faced regarding Communication and Interaction.

The results obtained from filling out the survey instrument, as shown in Table 2, showed that half of the respondents had a neutral response to the statements. Moreover, there is an almost equal distribution of agreeing and disagreeing in terms of having trouble in communicating with their instructors or classmates. On the other hand, when students were asked if they are having difficulty in communicating with their peers in respect to group and collaborative projects, almost half of the respondents have a neutral response, but a large portion of the others have agreed that they are encountering some difficulties. 
Table 2: Communication and Interaction

\begin{tabular}{|l|l|l|l|c|c|c|c|}
\hline \multirow{2}{*}{ Question } & Mean & SD & $\begin{array}{c}\text { Strongly } \\
\text { Disagree }\end{array}$ & Disagree & Neutral & Agree & $\begin{array}{c}\text { Strongly } \\
\text { Agree }\end{array}$ \\
\hline $\begin{array}{l}\text { Difficulty of } \\
\text { communicating } \\
\text { with your } \\
\text { instructor }\end{array}$ & 2.969 & 0.791 & 3.6 & 20.7 & 52.5 & 21.9 & 1.4 \\
\hline $\begin{array}{l}\text { Difficulty of } \\
\text { communicating } \\
\text { with your } \\
\text { classmates }\end{array}$ & 2.971 & 0.902 & 5.5 & 22.3 & 45.1 & 23.8 & 3.3 \\
\hline $\begin{array}{l}\text { Difficulty in } \\
\text { communication in } \\
\text { terms of group or } \\
\text { collaboration } \\
\text { projects }\end{array}$ & 3.219 & 0.973 & 3.8 & 17.8 & 40.6 & 28.3 & 9.5 \\
\hline
\end{tabular}

Table 3: Communication and Interaction

\begin{tabular}{|l|c|c|c|c|c|c|c|}
\hline \multirow{2}{*}{ Question } & Mean & SD & $\begin{array}{c}\text { Strongly } \\
\text { Disagree }\end{array}$ & Disagree & Neutral & Agree & $\begin{array}{c}\text { Strongly } \\
\text { Agree }\end{array}$ \\
\hline $\begin{array}{l}\text { Poor delivery of } \\
\text { instructions }\end{array}$ & 2.722 & 0.778 & 5.5 & 30.9 & 50.4 & 12.6 & 0.7 \\
\hline $\begin{array}{l}\text { Unavailability of } \\
\text { technical support } \\
\text { from the instructor }\end{array}$ & 2.800 & 0.807 & 3.6 & 31.8 & 47.5 & 15.2 & 1.9 \\
\hline $\begin{array}{l}\text { Poor interaction } \\
\text { during classes }\end{array}$ & 2.834 & 0.860 & 3.6 & 33.0 & 42.8 & 17.8 & 2.9 \\
\hline
\end{tabular}

Question 2: Student Perceptions towards the Challenges faced regarding Teaching Methodologies.

As shown in table 3, half of the responses are neutral when asked if there is a poor delivery of instruction, availability of technical support from the instructor and if there is poor interaction during classes which covers $50.4 \%, 47.5 \%$, and $42.8 \%$ of the responses respectively. However, the majority of the remaining respondents disagreed with the statements. This can be interpreted that a small portion of the total number of respondents agrees that the teaching methodologies used by the instructors are somehow effective and are delivered in an acceptable manner. Also, support from the instructors is available. And there is an acceptable level of interaction between the instructor and students during classes. 
Table 4: Communication and Interaction

\begin{tabular}{|l|c|c|c|c|c|c|c|}
\hline \multirow{2}{*}{ Question } & Mean & SD & $\begin{array}{c}\text { Strongly } \\
\text { Disagree }\end{array}$ & Disagree & Neutral & Agree & $\begin{array}{c}\text { Strongly } \\
\text { Agree }\end{array}$ \\
\hline $\begin{array}{l}\text { Lack of } \\
\text { instructional } \\
\text { materials provided }\end{array}$ & 2.765 & 0.905 & 5.2 & 35.9 & 39.9 & 15.2 & 3.8 \\
\hline $\begin{array}{l}\text { Lack of } \\
\text { gadgets/devices } \\
\text { used in online } \\
\text { classes }\end{array}$ & 3.086 & 0.975 & 4.3 & 23.5 & 38.7 & 26.4 & 7.1 \\
\hline $\begin{array}{l}\text { Poor internet } \\
\text { connectivity }\end{array}$ & 3.572 & 0.987 & 1.9 & 10.9 & 34.9 & 32.5 & 19.7 \\
\hline
\end{tabular}

Question 3: Student Perceptions towards the Challenges faced regarding Learning Resources and Economic Burden.

The majority of the students have responded that they are neutral $(39.9 \%)$ when asked about their level of agreement on the lack of instructional materials provided by the instructors. However, a large portion disagreed that the instructors are lacking in those aspects with a response percentage of $35.9 \%$ and $5.2 \%$ on disagree and strongly disagree, respectively. When asked about their level of agreement in their experiences in lacking devices to be used in online classes, still, the majority of the responses are neutral. Moreover, the result showed that the students are still experiencing poor and unstable internet connections $(\mathrm{M}=3.572)$.

\subsection{Open-Ended Questions}

Table 5: Recurring theme on the Open-Ended Questions

\begin{tabular}{|l|l|}
\hline \multicolumn{2}{|c|}{ Recurring Themes } \\
\hline $\begin{array}{l}\text { Question 1: How was your } \\
\text { experience communicating } \\
\text { with your classmates and } \\
\text { instructors? }\end{array}$ & Some instructors are approachable and considerate. \\
\cline { 2 - 2 } & Instructors took weeks to respond. \\
\cline { 2 - 2 } & $\begin{array}{l}\text { There is a problem in communication when it comes to } \\
\text { group work and collaboration. }\end{array}$ \\
\hline $\begin{array}{l}\text { Question 2: What are the } \\
\text { specific difficulties you } \\
\text { encountered, if any, during } \\
\text { online classes? }\end{array}$ & Poor/Unstable Internet Connection. \\
\cline { 2 - 2 } & Noise / Human and pets' intrusion. \\
\cline { 2 - 2 } & Communication and Time Management. \\
\cline { 2 - 2 } & Delivery of Learning. \\
\hline
\end{tabular}

As shown in Table 5, respondents were asked two (2) open-ended questions for them to freely answer their experiences and challenges encountered in the online 
classes. Qualitative data taken from the responses to the questions were analysed, and recurrent themes were identified. The open-ended questions received responses ranging from one-word answers to paragraph-length thoughts. Additionally, some of the responses do not genuinely answer the questions being asked which in result were deemed unreliable. Only 299 responses from question number 1 and 399 responses from question number 2 were considered usable, which are $71 \%$, and $95 \%$ of the total number of responses, respectively. The recurring themes of the answers were matched to the challenges identified earlier.

\section{Question 1}

In question number 1 , the recurring themes observed from the answers of the students can be categorized based on the people involved, which are their classmates and their instructors. In terms of the communication between the students and their instructors, two main recurrent themes were observed: one of which is positive, and the other is negative. The students find the instructors approachable and considerate. As some of the students said:

"If I have something to ask that I don't understand they are very responsive" and "It was fine communicating with my classmates and some of my instructors since we can message them from messenger or we can email them if ever there were things we cannot understand from the topics they discussed".

This shows that despite the situation, some of the students still consider their instructors are responsive and available to contact in other communication platforms.

On the contrary, there are students who expressed their dismay and bad experience when it comes to communicating with their instructors. Some of the students said that:

"Sometimes it takes weeks before some instructors reply on our questions using emails", "the response from some instructors take a long time", "instructors hardly communicate outside of Google Meet.", "As for the instructors, some are somewhat unapproachable".

Comparing the statements earlier to these statements, it can be observed that some of the instructors do not communicate using alternative platform. This could be the reason why some of the messages of the students are not answered instantaneously or as soon as possible. As one student said:

"Communicating with our instructors was not that good because you need to send private emails to them. Although it is possible, I think that it will be much easier if we can communicate with them through messenger/FB.".

Some students shared that they are hesitant in communicating with their instruction due to shyness or fear. Some of them are afraid to ask their instructors for clarification. As quoted in the following statements by some students in response to the question: "How was your experience communicating with your classmates and instructors?". 
In terms of communication between a student and their classmates, two opposite themes were observed. Some of the students shared that there is good communication between their classmates. Students answered the question with:

"My current classmates are cooperative and considerate, as if they were kind enough to perform our teamwork" and "I experienced that my classmates are very helpful in every time that we didn't understand the activities, I ask some of my classmates and I am thankful for that kind of classmates".

There are even students, probably first-year students, who were able to develop friendships with their classmates despite not being able to meet in person. As one of the students said:

"I already made friends with my classmates even though it is an online class".

In addition, some students have learned to deal with communication difficulties. As seen in this response to the question from one student:

"At first it was really hard. But as time passed by, we are exercising on how to communicate properly with each other".

On the other hand, there are students who think that there is an existing problem in communicating with their classmates. Problems encountered typically happen when they are given a group task that needs them to collaborate with each other. As students have put it in describing what she experienced:

"It is difficult to communicate especially when we are doing groupings, mostly only one will do the work and it is unfair", "Kind of difficult in terms of group collaboration", and "I see, and experience being left out because they do not want to open up with other classmates".

This shows that students are encountering difficulties in communicating with their classmates in terms of group collaborative projects.

Moreover, difficulty in communication with their classmates are rooted from the reason that there are students who have personal matters to attend to and prioritize. One of the students put it in the description as:

"It is difficult to communicate with classmates because some of them have work".

Other related aspects observed were the problems that they encounter with background noises, unavailability of devices, and unstable internet access. A student state that:

"It is hard sometimes communicating with my classmates because not all of us have reliable internet and some have no means of buying gadgets".

This shows that the unavailability or slow speed of the internet is a contributing factor in hindering the students in having good communication with their classmates. 
Question 2

The students were asked to answer specific difficulties that they encountered, and they mentioned several of them. Table 5 shows the four main themes that the students identified as hard based on their replies to the second open-ended question.

In the technological aspect, one of the students answered that the challenge he encountered is

"The unreliable internet connection which makes it difficult to students to understand the instructor or his/her classmates while having an online discussion". Also, another student commented: "When the internet connection is poor, while the teacher is discussing the lesson. In the end, I didn't understand the lesson".

This shows that one of the main recurring themes is that the students are having trouble with their internet connection. This can be attributed to the countries' average internet speed which is known to be slow compared to its neighboring countries like Singapore and Thailand (Natividad, 2021). This problem leads to several issues raised by the students such as the fact that it affects how they understand and hear the discussion because the sound is choppy, being delayed or late in submitting activities due to attaching file issues and answering online quizzes and examinations. Another theme related to technology is the availability of the required device. The students said that:

"Device does not support the program needed to compile", "I do not have a laptop so sometimes I cannot do the things I should do with my phone", and "The gadgets or mediums that I have for the online class are still not that advanced, compared to what specs are preferable in the present times".

As computer studies students, they are taught to use software applications to support learning especially in classes that have laboratory activities like programming. However, some students are not well equipped with the devices that can support the software programs which need high device specifications as minimum requirements.

Another recurring theme found is more of a concern about the instructors and delivery of learning. Some of the students stated that:

"One of my instructors is lazy in terms of updating and teaching us", "[The challenge I encountered is] the schedule of the class because sometimes some instructors does not announce the time of class resulting to me not being able to join the class", "Lack of actual demonstration", and "Sometimes lack in explaining the lessons properly. Not elaborated".

This shows that there are still some lapses by some of the instructors in delivering the instructions and handling the online classes.

Aside from that, another recurring theme lies within the Human and Pets' Intrusion domain. As the student has said 
"Our surrounding is sometimes too noisy" and "I also find it hard to study here in our home because I feel like the environment is not suitable for it".

Students are having trouble focusing on the discussion since there are distractions.

Another common theme recurring in the answer was in the communication domain. This is one of the assertions that some students struggled with, as indicated above in the section on students' perceptions. The following statements were mentioned by the students:

"Communication when I have some questions in mind and some activities", "Communication with instructors through social media messaging application", and "When it comes to group work it is hard to collaborate with the other members".

It was also apparent that the students whose concerns are related to the communication domain also encountered troubles in time management. Some of these are also working students.

The results of the study shows that there are several concerns regarding the encountered challenges during the online classes that need to be taken into account: First, the communication and interaction between instructors and students and vice versa. Second, the delivery of the instructions. Instructors should be engaged in ensuring that the students learned from the course and provides assessment tools to identify such; And third, instructors should, at least, help ease the technical dilemmas experienced by the students. Although there were sample size and study limitations, this research could be considered in improving the conduct of online classes.

\section{Recommendations}

Based on the findings gained from the quantitative and qualitative results, the following recommendations are proposed for faculty, curriculum and instruction designers, and academic administrators:

Communication, Social interaction, and presence. Since students participate in online classes from different locations, they are restricted to have the option to meet or speak with their peers (Martin et al., 2018). It is critical that, aside from lectures, online classes allow students to communicate, ask for support, and establish bonds and relationship with their peers. On the other hand, communication with instructors should also be given attention because it can affect the learning of a student. There should be a clear, available, and accessible schedule for the consultation hours that will be agreed upon by both the students and instructors apart from the actual class schedule. Also, the instructors should specify what platform they will be using for the consultation.

Lapses in delivery of instructors. One factor seen to be affecting how the students immerse with the lessons delivered to them is their motivation. It is imperative 
for the instructor to make use of an effective strategy that could encourage deep engagement. The instructors should, at least, provide more engagement activities that will strengthen social interaction amongst the students and strategize on how to teach his lessons that will motivate the students to participate during class discussion. In Kearns's (2012) study, in sake of efficiency, it is recommended to look for chances to provide feedback to the whole class as opposed to individual students. Also, there should be constant monitoring and observation on the part of faculty members by the program coordinators and/or the Dean of the College to make sure that the faculty members are conducting their classes based on the given class schedule. The instructors should also attend webinars and training relative to the field of their specialization to further improve their teaching and have mastery in the courses assigned to them.

Technology and Noise. Friedman (2020) says that staying in touch with the instructor and informing them about the student's technical challenges is vital in order to overcome the student's technical issues. Students should be given sufficient instructions on how to use the online learning environment. Also, if permitted, the instructors may try to look for a more suitable means on how to conduct their classes to avoid or, at least, lessen the problem identified. There are platforms that contain features that can reduce the noise of the surroundings if not eliminated.

\section{Conclusion}

The researchers aimed to identify the students' experiences and challenges encountered when it comes to online learning. In this study, a concurrent nested mixed-methods approach was employed. It was carried out through the use of a Google Forms-based questionnaire. This study concludes that the computer studies students in Laguna State Polytechnic University-San Pablo City campus identified and experienced several challenges during their online classes. Recurring themes that emerged from the findings are communication, feedback, and social interaction issues, delivering teaching and learning issues, technical issues, and noise and human intrusion. The findings of the survey questionnaire indicated that about half of the respondents gave a neutral response, however, the majority of the non-neutral respondents acknowledged that communicating with their classmates, especially in group collaborative projects, is proving tough. Furthermore, the findings revealed that the instructors' teaching methodologies are effective and delivered in a satisfactory manner. In terms of the technical issues in online classes, the result showed that the students continue to have inadequate and unreliable internet connections and experience distraction from noise and people around them in their homes. The study's findings are also seen to serve as baseline information for the college to redesign or revise policies that are relevant and responsive to the coming semesters. This study has implications for informing faculty, curriculum and instruction designers, and academic administrators about the students' needs and what areas should be considered to improve teaching and learning delivery in the coming semesters and academic years 


\section{Limitation and Future Research}

However, there were certain drawbacks to this study, such as the fact that the findings could not be generalized. It is suggested to conduct research specific to the challenges encountered such as communication, interaction, collaboration, and lapses in teaching delivery with more equitable methodologies, sampling, and analyses. On the other hand, instead of focusing on the challenges, the study may focus on examining the impact of online learning on students' performance, grades, or achievements. Furthermore, this study only looked at the challenges encountered by the students, and it is possible that the study's scope will be expanded in the future to include institutions as well as statements from educators who are active in online learning.

\section{References}

Adedoyin, O. B., \& Soykan, E. (2020). Covid-19 pandemic and online learning: the challenges and opportunities. Interactive Learning Environments. https://doi.org/10.1080/10494820.2020.1813180

Alam, A. (2020). Challenges and Possibilities of Online Education during Covid-19. Preprints 2020. https://doi.org/10.20944/preprints202006.0013.v1

Almaiah, M. A., Al-Khasawneh, A., \& Althunibat, A. (2020). Exploring the critical challenges and factors influencing the E-learning system usage during COVID19 pandemic. Education and Information Technologies, 25, 5261-5280. https://doi.org/10.1007/s10639-020-10219-y

Anshari, M., Alas, Y., Sabtu, N. P. H., \& Hamid, M. S. A. (2016). Online Learning: trends, issues and challenges in the Big Data Era. Journal of e-Learning and Knowledge Society, 12(1). https://www.learntechlib.org/p/171433/

Barrot, J. S., Llenares, I. I. \& del Rosario, L. S. (2021). Students' online learning challenges during the pandemic and how they cope with them: The case of the Philippines. Educ Inf Technol 26, 7321-7338. https:/ / doi.org/10.1007/s10639-021-10589-x

Braun, V., \& Clarke, V. (2006). Using thematic analysis in psychology. Qualitative Research in Psychology, 3(2), 77-101. doi:http://dx.doi.org/10.1191/1478088706qp063oa

Callo, E. C., \& Yazon, A. D. (2020). Exploring the factors influencing the readiness of faculty and students on online teaching and learning as an alternative delivery mode for the new normal. Universal Journal of Educational Research, 8(8), 35093518. https://doi.org/10.13189/ujer.2020.080826

Cheng, X. (2020). Challenges of'school's out, but class's on'to school education: Practical exploration of Chinese schools during the COVID-19 Pandemic. Sci Insigt Edu Front, 5(2), 501-516. https://doi.org/10.15354/sief.20.ar043

Chiu, T. K. F., Lin, T. J. \& Lonka, K. (2021) Motivating Online Learning: The Challenges of COVID-19 and Beyond. Asia-Pacific Edu Res 30, 187-190. https://doi.org/10.1007/s40299-021-00566-w

De Vera III, J. (2019). CHED COVID Advisory No. 2 - Guidelines for Prevention, Control, and Mitigation of the Spread of Coronavirus Disease 2019 (COVID-19) in Higher Education Institutions (HEIs). Commission on Higher Education. https://ched.gov.ph/wp-content/uploads/CHED-COVID-2019-Advisory-No.2.pdf

Friedman, J. (2020). Tackle Challenges of Online Classes due to COVID-19, US News. https:// www.usnews.com/education/best-colleges/articles/how-to-overcomechallenges-of-online-classes-due-to-coronavirus 
Gilbert, B. (2015). Online learning revealing the benefits and challenges. Education Masters. Paper

303. https:/ / fisherpub.sjfc.edu/cgi/viewcontent.cgi?article=1304\&context=educatio n_ETD_masters

Gillett-Swan, J. (2017). The challenges of online learning: Supporting and engaging the isolated learner. Journal of Learning Design, 10(1), 20-30. https://doi.org/10.5204/jld.v9i3.293

Hermanto, Y. B., \& Srimulyani, V. A. (2021). The challenges of online learning during the covid-19 pandemic. Jurnal Pendidikan Dan Pengajaran, 54(1), 46-57. http://dx.doi.org/10.23887/jpp.v54i1.29703

Kearns, L. R. (2012). Student assessment in online learning: Challenges and effective practices. Journal of Online Learning and Teaching, 8(3), 198. https://jolt.merlot.org/vol8no3/kearns_0912.pdf

Koh, M. H., \& Hill, J. R. (2009). Student perceptions of groupwork in an online course: Benefits and challenges. International Journal of E-Learning $\mathcal{E}$ Distance Education/Revue internationale du e-learning et la formation à distance, 23(2), 69-92. http://www.ijede.ca/index.php/jde/article/view/477

Kumar, S. (2015). 5 Common Problems Faced by Students In eLearning And how to Overcome Them. eLEarning Industry. https://elearningindustry.com/5common-problems-faced-by-students-in-elearning-overcome.

Martin, F., Stamper, B., \& Flowers, C. (2020). Examining student perception of their readiness for online learning: Importance and confidence. Online Learning, 24(2), 38-58. https://doi.org/10.24059/olj.v24i2.2053

Natividad, N. (2021). Why Internet Speeds in the Philippines Are So Slow. Vice World News. $\quad$ https://www.vice.com/en/article/n7vy3m/why-internet-speedsphilippines-slow-laws

Pappas, C. (2014). Top 5 Most Common eLearning Challenges and How To Overcome Them. eLearning Industry. https://elearningindustry.com/5-common-elearningchallenges-overcome.

Ribeiro, R. (2020). How University Faculty Embraced the Remote Learning Shift. EdTech Magazine. https://edtechmagazine.com/higher/article/2020/04/howuniversity-faculty-embraced-remote-learning-shift

Saul, C. (2004). An overview of online learning. Second edition Chapter 1: an introduction to online learning

Sutton, J., \& Austin, Z. (2015). Qualitative research: Data collection, analysis, and management. The Canadian Journal of Hospital Pharmacy, 68(3), 226-231. PMC4485510. Retrieved from https://www.ncbi.nlm.nih.gov/pmc/articles/PMC4485510/

Swart, R. (2019). Thematic analysis of survey responses from undergraduate students. In SAGE Research Methods Datasets Part 2. SAGE Publications, Ltd. https://dx.doi.org/10.4135/9781526468666

Yusuf, B. N., \& Ahmad, J. (2020). Are we prepared enough? A case study of challenges in online learning in a private higher learning institution during the Covid-19 outbreaks. Advances in Social Sciences Research Journal, 7(5), 205-212. https:// doi.org/10.14738/assrj.75.8211 